\title{
Elaboration and evaluation of produced hamburger with meat of old sheep and pig with added of chia seed (Salvia hispanica)
}

Jarbas Machado de Melo ${ }^{1}$, Rafaela Nery de Melo ${ }^{1}$, Sirineu José Sicheski ${ }^{1}$, Bruna Isabela Daniel ${ }^{2}$, Andressa Perissinotto ${ }^{2}$, Marcelo Urban Janeczko ${ }^{3}$, Maiki Roberto Detofol ${ }^{4}$, Mónica Beatriz Alvarado Soares ${ }^{3}$, Rogerio Luis Cansian ${ }^{3}$

${ }^{1}$ Food Technology, Instituto Federal Farroupilha, Campus Santo Augusto, Santo Augusto, RS, Brazil

${ }^{2}$ Department of Health Science, URI - Erechim, RS, Brazil

${ }^{3}$ Department of Food Engineering, URI - Erechim, RS, Brazil

${ }^{4}$ Department of Chemistry, URI - Erechim, RS, Brazil

Email address:

jarbas.melo@iffarroupilha.edu.br (J. M. Melo), alvarado@uricer.edu.br (M. B. A. Soares), cansian@uricer.edu.br (R. L.Cansian)

\section{To cite this article:}

Jarbas Machado de Melo, Rafaela Nery de Melo, Sirineu José Sicheski, Bruna Isabela Daniel, Andressa Perissinotto, Marcelo Urban Janeczko, Maiki Roberto Detofol, Mónica Beatriz Alvarado Soares, Rogerio Luis Cansian. Elaboration and Evaluation of Produced Hamburger with Meat of Old Sheep and Pig with Added of Chia Seed (Salvia hispanica). International Journal of Nutrition and Food Sciences.

Vol. 4, No. 1, 2015, pp. 14-18. doi: 10.11648/j.ijnfs.20150401.13

\begin{abstract}
The objective of this study was to develop some hamburger meat product aimed at harnessing meat of old sheep, of little acceptance in nature, with pork and chia seed. The better acceptance formulation was used to prepare three formulations the relationship being of sheep/pork of $50 / 50(\mathrm{w} / \mathrm{w})$ and chia seed concentrations of $0 \%, 2 \%$ and $4 \%$. The results showed significant difference $(\mathrm{p}<0.05)$ acceptability among FA formulations (without chia seed) and FC (4\% chia seed) at 120 days and between FC formulation at 90 and 120 days. The chemical composition was significantly affected by the addition of chia seed. The cooking weight loss was ranging from $11.6 \%$ (FC) to $19.29 \%$ (FA). In the evaluation of TBARS and IP it was verified interference in the formulations by the addition of chia seed. The use of chia seed these burgers can be recommended up to $4 \%$.
\end{abstract}

Keywords: Burger, Sheep Meat, Chia Seed, Sensory Analysis

\section{Introduction}

In Brazil, the sheep industry is being focused for termination of lambs owing to demand for consumer centers, that require high quality sheep meat and present sensory properties such as the presence of low-fat and softness. Though, as a result of this production takes place annually disposing of animals with advanced age or sheep in the final stages of reproductive life, which are difficult to be commercialized. The meat of this category is characterized by excess fat, firmer texture, more intense odor and dark color, resulting in lower sensory quality when compared with lambs. An alternative would be to use their processing in developing burger for their sensory characteristics, speed of preparation and long shelf life, are products that can also allow the incorporation of functional ingredients enhancing their quality.
The chia seed (Salvia hispanica) is considered one of the highest known sources vegetative fatty acid linoleic, since besides the main component omega 3 shows fiber, calcium, potassium, magnesium and protein [1].

Thus, this research aimed to develop a meat-like product with hamburger meat of old sheep, pig and chia seed (Salvia hispanica). Sensory analysis, physical chemistry and assessment of shelf-life were performed.

\section{Materials and Methods}

\subsection{Processing Burger}

Four sheep with 5-6 years of age, Texel breed, body condition score 3 [2] were used. The slaughter took place in fridge Salvati and animals obeyed the rules of pre-slaughter management. The carcasses were kept in cold storage at $4{ }^{\circ} \mathrm{C}$ for 24 hours and subsequently were boned the loin, shank and 
palette for use in the formulation of burgers in equal proportions. The pork pernil was obtained in the local market. The chia seed (Salvia hispanica) Pazze mark was obtained directly from industry and own blend of hamburger IBRAC Brazilian Industry of Additives and Spices Ltda.

In the process of preparing the burgers sheep and pork meat were blown away in grinder (G. Paniz, MC22 model) with 5 $\mathrm{mm}$ diameter disc. After grinding the meats were mixed by hand for about 5 minutes. Thereafter was added the mixture itself hamburger in the proportion of $4 \%(\mathrm{w} / \mathrm{w})$, related to the weight of the mixture of meat mixture and a mixture of both manually for 2 to 3 minutes. Then added chia seed or not previously crushed in a blender (Philips Walita, RI2008/40 model) according to formulation. This mass obtained was homogenized with the ingredients by hand for about 10 minutes. The burgers were modeled manually with an average weight of 80 grams, packaged and labeled in plastic films (Apex Packaging - coextruded film of nylon-poly) and frozen at $-18^{\circ} \mathrm{C}$ in a freezer till perform the analyzes. In the formulation of the burgers in the first stage $2^{2}$ experimental design was used according to Table 1 , and the independent variables were the ratio of sheep meat/pork $(\%)$ and addition of chia seed (\%), and the dependent variable was evaluated global acceptance.

In the second step, results obtained from the three formulations were prepared. Has set itself the percentage of sheep meat/pork $(50 / 50, \mathrm{~m} / \mathrm{m})$ and mix to hamburger. The formulation (FA) was prepared without seed, formulation $\mathrm{B}$ (FB) with $2 \%$ and formulation $\mathrm{C}$ (FC) with $4 \%$ chia seed.

Table 1. Values used on Experimental design in $2^{2}$ for the production of hamburger

\begin{tabular}{llll}
\hline \multirow{2}{*}{ Variable } & Levels & \\
\cline { 2 - 4 } & $\mathbf{- 1}$ & $\mathbf{0}$ & $\mathbf{1}$ \\
\hline Relation sheep meat/pork (\%) & $30 / 70$ & $50 / 50$ & $70 / 30$ \\
Chia Seed $(\%)$ & 0 & 2 & 4 \\
\hline
\end{tabular}

\subsection{Microbiological Analysis}

To submit samples to the sensory acceptance tests, microbiological analysis of fecal coliforms, coagulase positive Staphylococcus, sulphite reducing Clostridium and Salmonella sp. were performed, according to methods described in the Normative Instruction n. 62 of MAPA [3].

\subsection{Sensorial analysis}

The sensorial evaluation in the first and second stage, were performed acceptance tests one day after the results of the microbiological analysis. In the first stage of evaluation of five formulations with the participation of 35 not trained tasters, of both sexes and of different age groups (14-48 years). Three formulations were used and evaluated from 60, 90 and 120 days with the participation of 28,32 and 31 tasters, respectively, for the second stage of evaluation. Evaluations occurred in individual booths and samples of 15-20 grams were served as cubes and presented in white plastic dishes immediately after cooking (grilled) sheet greased with vegetable oil heated up to $71^{\circ} \mathrm{C}$ [4]. The presentation occurred in a balanced way with the use of the identification label to each sample, with three-digit random number and a sheet for identification and evaluation of the samples was used Hedonic Scale Test Structured 9 points (1 - dislike extremely to 9 liked extremely) [5].

\subsection{Physical and Chemical Analyzes}

The Chemical composition: moisture determination (indirect gravimetric method at $105^{\circ} \mathrm{C}$ ), protein (Kjeldahl method), lipids (Soxhlet method), ash content (method of incineration in a muffle at $550^{\circ} \mathrm{C}$ ), the fibers enzymatic-gravimetric method was performed according to AOAC [6]. The total carbohydrates were calculated by difference.

The determination of weight loss by cooking (PPC) was determined as Cañeque et al. [7].

The $\mathrm{pH}$ was determined by electrometric method and water activity (Aw) in Aqua-lab apparatus according to AOAC [6].

The peroxide according to the methodology described by the Institute Adolfo Lutz and TBARS by the method described by Raharjo et al. [8] was performed.

The physic-chemical analyzes were performed in duplicate, except for the determination of Weight Loss for cooking which was performed in triplicate.

\subsection{Evaluations of the Shelf Life}

The shelf-life was assessed at time 30, 60, 90 and 120 analyzes of $\mathrm{pH}$, water activity, peroxide value and TBARS were performed.

\subsection{Statistical Analyzes}

The results obtained in acceptance testing in both phases of the experiment and the physic-chemical analyzes were subjected to analysis of variance (ANOVA) and Tukey Test ( $p$ $<0.05$ ), using the statistical software ASSISTAT 7.6 beta [9].

\section{Results and Discussion}

The results of the microbiological analysis of fecal coliforms $\left(1.1 \times 10^{2}\right.$ to $\left.3.4 \times 10^{2} \mathrm{MPN}\right)$ coagulase positive Staphylococcus $\left(<1.0 \times 10^{2} \mathrm{CFU}\right)$, sulphite reducing Clostridium (2.0 x $10^{1}$ to $\left.7.0 \times 10^{1} \mathrm{CFU}\right)$ and absence of Salmonella in different hamburger formulations, revealed satisfactory conditions of products for human consumption, indicating Good Manufacturing Practices and allowing them to be consumed in the sensory analysis.

According to that shown in Table 2, it can be seen that the mean of triplicate focal point (F5, F6 and F7) was 7.82, and the highest mean scores presented in formulation F5 (8.0), but not differ statistically the significance level of 5\% (Tukey test) formulations: F1, F3 and F4. In comparing the F2 and F4 both showed the same amount of meat, varying only in the amount of chia seed, but without significant difference $(\mathrm{p}<0.05)$. From these data it is concluded that the chia seed does not interfere with the results of sensory analysis, because their presence was not noticed by the panelists. 
Table 2. Experimental Matrix Planning $2^{2}$ encoded (real) values and responses in general acceptance on the first day after preparation of the formulation

\begin{tabular}{llll}
\hline \multirow{2}{*}{ Tests } & \multicolumn{2}{l}{ Independent Variables } & \multirow{2}{*}{ General Acceptance } \\
\cline { 2 - 3 } & $\mathbf{X}_{\mathbf{1}}$ & $\mathbf{X}_{\mathbf{2}}$ & $7.48^{\mathrm{a}} \pm 1.23$ \\
\hline 1 & $-1(30 / 70)$ & $-1(0)$ & $6.51^{\mathrm{bc}} \pm 1.22$ \\
2 & $1(70 / 30)$ & $-1(0)$ & $7.27^{\mathrm{ab}} \pm 1.42$ \\
3 & $-1(30 / 70)$ & $1(4)$ & $6.95^{\mathrm{ac}} \pm 1.44$ \\
4 & $1(70 / 30)$ & $1(4)$ & $8.00^{\mathrm{a}} \pm 0.82$ \\
5 & $0(50 / 50)$ & $0(2)$ & $7.63^{\mathrm{a}} \pm 0.81$ \\
6 & $0(50 / 50)$ & $0(2)$ & $7.83^{\mathrm{a}} \pm 0.60$ \\
7 & $0(50 / 50)$ & $0(2)$ & \\
\hline
\end{tabular}

Studies have revealed that the chia seed has no foreign taste typically known as fish taste [10] by having a number of compounds with potent antioxidant activity, which prevent oxidation and change the taste [11].

It is found that there is significant difference $(\mathrm{p}<0.05)$ between the formulations of triplicate central point and F2 (Table 2). It is observed that the F5, F6 and F7 formulations that present only $2 \%$ of chia seed, lower than F4 and F2 above, by changing the quantities of meat, suggests that this change in the concentrations of ovine meat has significantly influenced $(\mathrm{p}<0.05)$ between the central point and the F2.

According Beserra et al. [12], the meat of older sheep is undervalued because of its dark lower sensory characteristics, foul odor, color and sharp flavor.

The results showed that F5 got an acceptance of $95.5 \%$ of responses from panelists, with values of 6 and 9 scale, with a higher frequency of hedonic responses to score 8 , which refers to the scale "liked so much" by obtaining frequency $45.5 \%$. In this sense, from the formulation F5 three formulations (FA, FB and FC) were prepared. The results of sensory evaluation are shown in Table 3.

Table 3. Average scores tastes (standard deviation) in the sensory analysis of general acceptance of the formulations of burger with 60, 90 and 120 days of storage

\begin{tabular}{llll}
\hline \multirow{2}{*}{ Formulation } & \multicolumn{4}{l}{ Score (Standard deviation) } \\
\cline { 2 - 4 } & $\mathbf{6 0}$ days & $\mathbf{9 0}$ days & $\mathbf{1 2 0}$ days \\
\hline FA & $7.89^{\mathrm{aA}} \pm 0.83$ & $8.25^{\mathrm{aA}} \pm 0.67$ & $8.03^{\mathrm{aA}} \pm 0.87$ \\
FB & $7.71^{\mathrm{aA}} \pm 0.76$ & $7.94^{\mathrm{aA}} \pm 0.71$ & $7.94^{\mathrm{abA}} \pm 0.98$ \\
FC & $7.82^{\mathrm{aAB}} \pm 0.90$ & $8.13^{\mathrm{aA}} \pm 0.91$ & $7.42^{\mathrm{bB}} \pm 1.06$ \\
\hline
\end{tabular}

FA (50/50 sheep: swine and without chia); FB (50/50 sheep: swine and 2\% chia); FC (50/50 sheep: swine and $4 \%$ chia); * Average scores \pm standard deviation followed by same letters lowercase capital Letters in the same column/line do not differ statistically at the 5\% level (Tukey test).

Table 3 shows a significant difference $(\mathrm{p}>0.05)$ between FA and FC formulations stored with 120 days of production. In evaluating the mean scores of the three formulations occurred in three distinct periods (60, 90 and 120 days) storage it was found that there was significant difference $(\mathrm{p}<$ 0.05 ) in sensory analysis within the same formulation between FC performed with time 90 and 120 days.

The FB formulation with 60 days had the highest frequency of responses with $63.7 \%$ panelists, who have given score 8 (like very much). While the assessment of burgers with 90 days, the highest frequency was observed with the FA formulation, obtaining score 9 (like extremely) by most tasters often of $54.5 \%$. For the 120 days of storage at higher frequency assigned by assessors occurred with the FC formulation with score 8 (like very much), which showed frequency of $54.5 \%$. In this sense, it can be seen that the chia seed, did not affect sensory acceptance because it was not perceived by the tasters.

Table 4. Centesimal composition of the three formulations burger made on the first day after preparation

\begin{tabular}{llll}
\hline \multirow{2}{*}{ Formulation } & \multicolumn{3}{l}{ Score (Standard deviation) } \\
\cline { 2 - 4 } & FA & FB & FC \\
\hline Protein, \% & $18.95^{\mathrm{a}} \pm 0.02$ & $18.50^{\mathrm{b}} \pm 0.02$ & $17.68^{\mathrm{c}} \pm 0.02$ \\
Lipids, \% & $1.44^{\mathrm{a}} \pm 0.02$ & $1.41^{\mathrm{a}} \pm 0.02$ & $1.41^{\mathrm{a}} \pm 0.02$ \\
Ash, \% & $3.9^{\mathrm{a}} \pm 0.02$ & $3.7^{\mathrm{b}} \pm 0.02$ & $3.54^{\mathrm{c}} \pm 0.02$ \\
Dietary Fiber, \%** & $<0.01^{\mathrm{c}} \pm 0.02$ & $0.68^{\mathrm{b}} \pm 0.02$ & $1.31^{\mathrm{a}} \pm 0.02$ \\
Carbohtdrates, \%** & $7.25^{\mathrm{c}} \pm 0.02$ & $7.33^{\mathrm{b}} \pm 0.02$ & $7.68^{\mathrm{a}} \pm 0.02$ \\
Humidity(\%/100\%) & $68.37^{\mathrm{a}} \pm 0.02$ & $68.37^{\mathrm{a}} \pm 0.02$ & $68.37^{\mathrm{b}} \pm 0.02$ \\
\hline
\end{tabular}

FA (50/50 sheep: swine and without chia); FB (50/50 sheep: swine and 2\% chia); FC (50/50 sheep: swine and 4\% chia); * Mean \pm standard deviation followed by the same letter are not significantly different at the $5 \%$ level (Tukey test); **Value on a dry basis.

The results on a dry basis regarding the chemical composition of the formulations in the second step are shown in Table 4 and allow observe that the increase in the amount of chia seed in the formulations has been a significant increase in dietary fiber and carbohydrate, and a significant decrease in protein and ash.

Results observed in a study with beef burger with added oatmeal obtained values of $60.06 \%$ and $73.54 \%$ moisture [13]. Similar experiment obtained values of $66.57 \%$ to $73.64 \%$ in sheep burgers enriched with oatmeal disposal [14]. Both studies smaller percentages of moisture occurred in the presence of oatmeal.

The chia seed presented as approximately residue 28 to $32 \%$ fiber, and 90 to $94 \%$ insoluble are formed of cellulose, hemicellulose and lignin, 6 to $10 \%$ are soluble composed of glucuronic acid and neutral sugars responsible for generating mucilage that is, the ability to bind water and form stable gels [15]. The high viscosity of chia seed mucilage becomes more likely to produce desired that the dietary fiber lower viscosity, such as beta-glucan, and guar gum effects [16]. Probably this feature of the soluble portion is the factor that has contributed in moisture values observed, that this portion is hydrophilic and has the ability to absorb more than 12 times its weight of water [1].

In the evaluation of values of fiber there was variation < $0.1 \%$ (FA) to $1.31 \%$ (FC) with a significant difference ( $\mathrm{p}<$ 0.05). According Seabra et al. [17], the advantages of the use of oatmeal in meat products justified due to water retention. There are reasons to use fibers in meat products, as are ingredients that promote health benefits because they have low calorific values can be used as partial fat substitutes, having excellent water retention capacity, and are neutral odor 
in ingredients with recognized functional properties [18].

Table 4 observed that the protein of the burgers had a variation of $18.95 \%$ to $17.68 \%$ and lipids between $1.44 \%$ to $1.41 \%$, both showed significant difference $(\mathrm{p}<0.05)$ between the formulations, but is in accordance with the Technical Rules of Identity and Quality burger, which establishes the maximum of $23 \%$ fat and a minimum of $15 \%$ protein for burger [19].

Meat products with low fat content may have reduced service life due to its water content is higher and therefore more conducive to microbiological growth [20]. According to the law all prepared formulations can be considered as "low fat" classification when the fat content of the product is less than $3 \%$, according to Decree 234 of $21 / 05 / 1996$ of the Ministry of Health [21].

The ash content (Table 4) also showed statistically significant differences $(\mathrm{p}<0.05)$, with values of $3.9 \%$ to $3.54 \%$, being higher than those recorded by Seabra et al. [17] found that levels of ash that ranged between $1.04 \%$ and $1.16 \%$ for hamburgers made only of sheep meat.

According to Marques [13] in a study with beef burger type products added oatmeal to ashes obtained values ranging from $2.58 \%$ to $2.90 \%$, while Santos et al. [14] reported ash contents varying between $1.49 \%$ to $3.85 \%$, where the formulations with maximum addition of $4 \%$ of oatmeal in burgers with sheep meat of disposing reached the highest percentage in this parameter.

Table 5 shows the results of weight loss by cooking for the different formulations, performed on the first day after preparation; there is a significant difference $(\mathrm{p}<0.05)$. There was a variation of $11.6 \%$ (FC) to $19.29 \%$ (FA), enabling reduction in weight loss with the addition of chia seed. It is due to thickener and/or emulsifying feature, which give the ability to capture water and fat molecules stabilizing the emulsion [22].
Table 5. Means values for Weight Loss Cooking (PPC) standard deviation of the types of hamburgers on the $1^{\text {st }}$ day after preparation

\begin{tabular}{ll}
\hline Formulation & Loss $(\%)^{*}$ \\
\hline FA & $19.29^{\mathrm{a}} \pm 0.98$ \\
FB & $14.64^{\mathrm{b}} \pm 1.00$ \\
FC & $11.60^{\mathrm{c}} \pm 1.56$ \\
\hline
\end{tabular}

* Average of \pm standard deviation of losses followed by the same letter is not significantly different at the $5 \%$ level (Tukey test).

Table 6 shows that there was a significant increase in $\mathrm{pH}$ due to the storage time. The greatest variation occurred in the formulation $\mathrm{FB}$. It is observed that the $\mathrm{pH}$ of the formulations was increased 120 days.

The Aw showed decreases of during the storage time and different formulations (Table 6). It is noted that the seed contributes to reduction of water activity and decreased the retention of free water, which can influence proliferation of microorganisms.

On Table 6 shows the evolution of the peroxide index during the storage time from 30 to 120 days, with the most obvious formulation occurred in FC. FA and FB in formulating the most noticeable difference was in the period of 120 days. Is possible to assign these differences by the amount of chia seed added to each formulation. One of the features that stand out most in chia seed is its content of essential fatty acids, with $19 \%$ linoleic acid and $63.8 \%$ of alpha linoleic acid [16].

Table 6 shows an increase in the amount of TBARS in the course of time it is verified, whereas there were more obvious in FC. In formulations FA and FB is observed significant difference at 120 days. The results may be interpreted as normal in frozen foods, since oxidative reactions proceed very slowly during the initial period of storage at temperatures below $-18^{\circ} \mathrm{C}$. Products with TBARS values below $1 \mathrm{mg}$ $\mathrm{Mal} / \mathrm{kg}$ do not normally add flavors and odors characteristic rancidity residual lipid oxidation [23].

Table 6. Average $\mathrm{pH}$ values and standard deviations of the hamburger formulations stored at $-18^{\circ} \mathrm{C}$ for $30,60,90$ and 120 days

\begin{tabular}{|c|c|c|c|c|}
\hline \multirow{2}{*}{ Formulations } & \multicolumn{4}{|l|}{ Days of Storage } \\
\hline & 30 & 60 & 90 & 120 \\
\hline \multicolumn{5}{|l|}{$\mathrm{pH}^{*}$} \\
\hline FA & $6.02^{\mathrm{bC}} \pm 0.01$ & $6.0^{\mathrm{bC}} \pm 0.01$ & $6.20^{\mathrm{aB}} \pm 0.01$ & $6.47^{\mathrm{aA}} \pm 0.01$ \\
\hline FB & $6.04^{\mathrm{bD}} \pm 0.01$ & $6.08^{\mathrm{Ac}} \pm 0.01$ & $6.17^{\mathrm{bB}} \pm 0.01$ & $6.34^{\mathrm{bA}} \pm 0.01$ \\
\hline FC & $6.13^{\mathrm{aB}} \pm 0.01$ & $6.11^{\mathrm{aB}} \pm 0.01$ & $6.19^{\mathrm{abB}} \pm 0.01$ & $6.34^{\mathrm{bA}} \pm 0.01$ \\
\hline \multicolumn{5}{|l|}{$\mathrm{Aw}^{*}$} \\
\hline FA & $0.973^{\mathrm{aA}} \pm 0.001$ & $0.965^{\mathrm{aB}} \pm 0.001$ & $0.964^{\mathrm{aB}} \pm 0.001$ & $0.964^{\mathrm{aB}} \pm 0.001$ \\
\hline FB & $0.970^{\mathrm{bA}} \pm 0.001$ & $0.963^{\mathrm{abB}} \pm 0.001$ & $0.963^{\mathrm{aB}} \pm 0.001$ & $0.962^{\mathrm{abB}} \pm 0.001$ \\
\hline $\mathrm{FC}$ & $0.965^{\mathrm{cA}} \pm 0.001$ & $0.961^{\mathrm{bB}} \pm 0.001$ & $0.962^{\mathrm{aB}} \pm 0.001$ & $0.960^{\mathrm{bB}} \pm 0.001$ \\
\hline \multicolumn{5}{|l|}{ Peroxide Index } \\
\hline FA & $0.48^{\mathrm{bB}} \pm 0.01$ & $0.47^{\mathrm{cBB}} \pm 0.01$ & $0.47^{\mathrm{bB}} \pm 0.01$ & $0.61^{\mathrm{Ca}} \pm 0.01$ \\
\hline $\mathrm{FB}$ & $0.46^{\mathrm{bBC}} \pm 0.01$ & $0.44^{\mathrm{bC}} \pm 0.01$ & $0.48^{\mathrm{bB}} \pm 0.01$ & $0.71^{\mathrm{ba}} \pm 0.01$ \\
\hline FC & $0.51^{\mathrm{aD}} \pm 0.01$ & $0.65^{\mathrm{aCB}} \pm 0.01$ & $0.79^{\mathrm{aB}} \pm 0.01$ & $1.19^{\mathrm{Aa}} \pm 0.01$ \\
\hline \multicolumn{5}{|l|}{ TBARS } \\
\hline FA & $0.23^{\mathrm{bB}} \pm 0.01$ & $0.20^{\mathrm{bB}} \pm 0.01$ & $0.20^{\mathrm{bB}} \pm 0.01$ & $0.29^{\mathrm{cA}} \pm 0.01$ \\
\hline FB & $0.19^{\mathrm{cB}} \pm 0.01$ & $0.18^{\mathrm{bB}} \pm 0.01$ & $0.20^{\mathrm{bB}} \pm 0.01$ & $0.37^{\mathrm{bA}} \pm 0.01$ \\
\hline $\mathrm{FC}$ & $0.26^{\mathrm{aD}} \pm 0.01$ & $0.31^{\mathrm{aC}} \pm 0.01$ & $0.37^{\mathrm{aB}} \pm 0.01$ & $0.52^{\mathrm{aA}} \pm 0.01$ \\
\hline
\end{tabular}

* Mean \pm standard deviation followed by same letters lowercase/uppercase in the same column/row does not differ statistically at the 5\% level (Tukey test). 


\section{Conclusions}

Under the nutritional aspect of the constituent chemical composition, dietary fiber and carbohydrates increased significantly with the addition of chia seed and their addition significantly improves weight loss by cooking. In sensory analysis observed the same had good acceptability. In the evaluation of IP and TBARS values are acceptable in time evaluation examined life (120 days) and can say that can be safely consumed up to 90 days. The elaborate hamburger type meat products can be considered as products of low-fat, and the meat of old sheep presented as an alternative to use, avoiding trade in nature.

\section{References}

[1] G. Tosco, Os benefícios da "chia" em humanos e animais. Atualidades Ornitológicas, 2004; 119: 7.

[2] M. F. Cezar, W. H. D. Sousa. Avaliação e utilização da condição corporal como ferramenta de melhoria da reprodução e produção de ovinos e caprinos de corte. In Reunião Anual da Sociedade Brasileira de Zootecnia, João Pessoa, PB, 2006; 649-678.

[3] Brazil, Métodos analíticos oficiais para análises microbiológicas para controle de produtos de origem animal e água, MAPA Ministério da Agricultura Pecuária e Abastecimento. Normativa No. $62 \quad$ (2003) (http://extranet.agricultura.gov.br).

[4] A. P. Arisseto, M. A. R. Pollonio. Avaliação da estabilidade oxidativa do hambúrguer tipo calabresa, formulado com reduzidos teores de nitrito e diferentes percentagens de gordura durante armazenamento congelado. Revista Higiene Alimentar, 2005; 19: 72-80.

[5] H. Stone, J. L. Sidel, Sensory evaluation practices. 2a ed. Academic Press. 1993; 337.

[6] Analytical Chemist Method. AOAC Official Method 2003.08, AOAC International, Gaithersburg, MD, USA. 2005.

[7] V. Cañeque, C. Perez, S. Velasco, Carcass and meat quality of light lambs using principal component analysis. Meat Sci., 2004; 67: 595-605.

[8] S. Raharjo, J. N. Sofos, G. R. Schimdt, Improved speed, specifity, and limit of determination of aqueous acid extraction thiobarbituric acid- $\mathrm{C}_{18}$ method for measuring lipid peroxidation in beef. J. Agric. Food Chem., 1992; 40: 2182-2185 .

[9] F. A. S. Silva, Assistat versão 7.6 beta. (2012). Campina Grande-PB: Assistência Estatística, Departamento de Engenharia Agrícola do CTRN - Universidade Federal de Campina Grande, Campus de Campina (2012).

[10] R. Ayerza, W. Coates. The omega-3 enriched eggs: the influence of dietary linolenic fatty acid source combination on egg production and composition. Can. J. Anim. Sci., 2001; 81: $355-362$.

[11] R. D. E. Castro-Martinez, D. E. Pratt, E. E. Miller, Natural antioxidants of chia seeds. In Proceedings of The World Conference on Emerging Technologies in the Fats and Oils Industry, edited and published by American Oil Chemist`s Society, Champaign, Illinois, USA. 1986; 382-396.

[12] F. F. Beserra, R. T. Nassu, L. R. R. Melo, M. C. P. Rodrigues, E. M. C. Silva. Manufacturing of a restructured hamlike product with goat meat. In: Ift Annual Meeting, Chicago. Book of Abstracts. 1999; 89.

[13] J. M. Marques, Elaboração de um produto de carne bovina "Tipo Hambúrguer" adicionado de farinha de aveia. Dissertation, Federal University of Paraná, Brazil. 2007.

[14] L. C. O. Santos Junior, R. Rizzatti, A. Brungera, T. J. Schiavm, E. F. M. Campos, J. F. S Neto, Rodrigues et al., Desenvolvimento de hambúrguer de carne de ovinos de descarte enriquecido com farinha de aveia. Cienc. Anim. Bras., 2009; 10: 1128-1134.

[15] J. M. Fili, Chía (Salvia Hispánica): aspectos nutricionales, aporte a una dieta saludable. Primera Jornada Técnica de Chía, una alternativa productiva para el NOA. INTA EEA Salta, Argentina. 2012.

[16] R. Ayerza, W. Coates. Ground chia seed and chia oil effects on plasma lipids and Fatty acids in the rat. Nutr. Res., 2005; 25: 995-1003.

[17] L. M. J. Seabra, J. F. F. Zapata, C. M. Nogueira, Fécula de mandioca e farinha de aveia como substitutos de gordura na formulação de hambúrguer de carne ovina. Cienc. Tecnol. Alim., 2002; 22: 244-248.

[18] A. C. S. Barreto. Efeito da adição de fibras como substitutos de gordura em mortadela. Thesis. Universidade Estadual de Campinas - Unicamp, Brazil. 2007.

[19] Brazil, Regulamento Técnico de Identidade e Qualidade de Hambúrguer, MAPA Ministério da Agricultura Pecuária e Abastecimento. Normativa No. 20; 2000 (http://www.agricultura.gov.br).

[20] F. J. Colmenero. Relevant factors in strategies for fat reduction in meat products. Trends Food Sci. Technol., 2000; 11: 56-66.

[21] Brazil, Normas técnicas referentes a alimentos para fins especiais, MAPA Ministério da Agricultura Pecuária e Abastecimento. Normativa No. 234; 1996.

[22] M. P. Salgado-Cruz, D. Cedillo-López, O. M. C. Beltrán, Estudio de las Propiedades Funcionales de la Semilla de Chía (Salvia hispánica) y de la Fibra Dietaria Obtenida de la Misma. Depto de graduados e investigación em Alimentos, Escuela Nacional de Ciencias Biologicas, I.P.N. Prol. de Carpio esq. Plan de Ayala Col. Sto. Tomas. M. México. D.F. VII Congreso Nacional de Ciencia de los Alimentos y III Foro de Ciencia y Tecnologia de Alimentos, Guanajuato, Mexico. 2005.

[23] R. Olivo, M. Shimokomaki, Carnes no caminho da pesquisa. Cocal do Sul: Imprint. 2001; 155. 